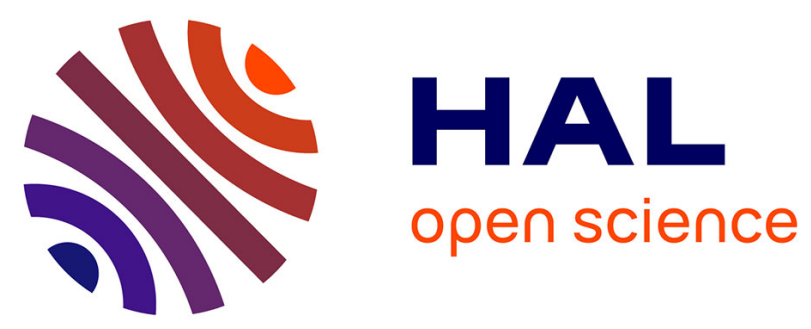

\title{
ENTREPRENEURSHIP AND OCCUPATIONAL CHOICE: GENETIC AND ENVIRONMENTAL INFLUENCES
}

Nicos Nicolaou, Scott Shane

\section{> To cite this version:}

Nicos Nicolaou, Scott Shane. ENTREPRENEURSHIP AND OCCUPATIONAL CHOICE: GENETIC AND ENVIRONMENTAL INFLUENCES. Journal of Economic Behavior and Organization, 2010, 76 (1), pp.3. 10.1016/j.jebo.2010.02.009 . hal-00856601

\section{HAL Id: hal-00856601 https://hal.science/hal-00856601}

Submitted on 2 Sep 2013

HAL is a multi-disciplinary open access archive for the deposit and dissemination of scientific research documents, whether they are published or not. The documents may come from teaching and research institutions in France or abroad, or from public or private research centers.
L'archive ouverte pluridisciplinaire HAL, est destinée au dépôt et à la diffusion de documents scientifiques de niveau recherche, publiés ou non, émanant des établissements d'enseignement et de recherche français ou étrangers, des laboratoires publics ou privés. 


\section{Accepted Manuscript}

Title: ENTREPRENEURSHIP AND OCCUPATIONAL CHOICE: GENETIC AND ENVIRONMENTAL INFLUENCES

Authors: Nicos Nicolaou, Scott Shane

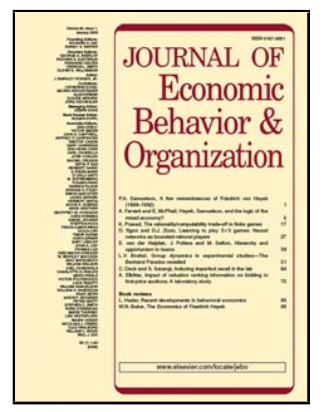

PII:

S0167-2681(10)00115-0

DOI: doi:10.1016/j.jebo.2010.02.009

Reference: JEBO 2556

To appear in: Journal of Economic Behavior \& Organization

Received date: $\quad 26-8-2009$

Revised date: $\quad 6-2-2010$

Accepted date: $\quad 18-2-2010$

Please cite this article as: Nicolaou, N., Shane, S., ENTREPRENEURSHIP AND OCCUPATIONAL CHOICE: GENETIC AND ENVIRONMENTAL INFLUENCES, Journal of Economic Behavior and Organization (2010), doi:10.1016/j.jebo.2010.02.009

This is a PDF file of an unedited manuscript that has been accepted for publication. As a service to our customers we are providing this early version of the manuscript. The manuscript will undergo copyediting, typesetting, and review of the resulting proof before it is published in its final form. Please note that during the production process errors may be discovered which could affect the content, and all legal disclaimers that apply to the journal pertain. 


\title{
ENTREPRENEURSHIP AND OCCUPATIONAL CHOICE: GENETIC AND
}

\author{
ENVIRONMENTAL INFLUENCES
}

\author{
Nicos Nicolaou \\ Department of Public and Business Administration, \\ University of Cyprus, \\ 1678 Nicosia, \\ Cyprus. \\ Tel: $+357-22-892464$ \\ Email: nicos.nicolaou@ucy.ac.cy
}

Scott Shane

Weatherhead School of Management,

Case Western Reserve University,

11119 Bellflower Rd.,

Cleveland, OH 44106.

Tel: 216-368-5538

Email: sas46@cwru.edu

Keywords: Entrepreneurship, Behavior Genetics, Occupational choice

JEL Classification: M13, M19

Acknowledgments: Acknowledgments: We would like to express our deepest gratitude to Philip Zepter and Home \& Art Sales Services AG for sponsoring part of this research. We would like to thank the Editors of the Special Issue and the anonymous reviewers for their insightful and constructive comments. 


\title{
ENTREPRENEURSHIP AND OCCUPATIONAL CHOICE: GENETIC AND \\ ENVIRONMENTAL INFLUENCES
}

\begin{abstract}
We applied quantitative genetics techniques to a sample of 347 pairs of monozygotic and 303 pairs of dizygotic twins taken from the MIDUS database to examine the influence of genetic factors on the variation across people in the tendency to be self-employed and to choose other occupations. We found that a heritability hypothesis is supported for the tendency to be selfemployed, both currently and ten years prior, with no influence of the shared environment. We also found that this heritability is substantive for male as well as female twins. Moreover, we found support for a heritability hypothesis for the intention to be self-employed in the future and for a bivariate heritability model between entrepreneurial intentions and the tendency to be self-employed. Finally, we found support for a heritability hypothesis for other occupational choices, specifically the choice to be a teacher, manager or salesperson.
\end{abstract}




\section{ENTREPRENEURSHIP AND OCCUPATIONAL CHOICE: GENETIC AND \\ ENVIRONMENTAL INFLUENCES}

\section{Introduction}

Recent research has shown that the tendency to become an entrepreneur is partially genetic. Using a sample of 870 pairs of monozygotic (MZ) and 857 pairs of same-sex dizygotic (DZ) twins, Nicolaou, Shane, et al. (2008) found that between 37 to 42 percent of the variance in four different measures of the tendency to be an entrepreneur is accounted for by genetic factors.

The finding that there is a genetic predisposition to engage in entrepreneurship has raised a number of questions: First, does genetics affect this tendency equally for both men and women? Observers have noted that the Nicolaou et al. (2008) paper looks at a largely female sample, and subsequent research by Zhang et al. (2009) shows that the genetic effect on the tendency to be an entrepreneur is stronger for women than for men. Therefore, genetic effects on the tendency to be an entrepreneur for a balanced sample of men and women might be smaller than those reported to date.

Second, how do genetic factors affect the tendency to be an entrepreneur? Additional research is required to examine the causal pathways through which genetic factors influence this tendency. Do genes influence the tendency to be an entrepreneur by affecting preferences for this occupation, thereby enhancing entrepreneurial intentions? While it is possible that genes could influence the ability to raise capital or organize businesses, a more likely scenario is that genes affect the tendency to become an entrepreneur by increasing entrepreneurial intentions.

Understanding the degree to which genetic factors influence both entrepreneurial intentions and the tendency to be an entrepreneur is important if we are to be prescriptive about entrepreneurship. If most of the covariance between entrepreneurial intentions and the tendency to be an entrepreneur is accounted for by genetic factors, then attempts to increase 
the number of entrepreneurs by influencing their entrepreneurial intentions are unlikely to be successful. If, on the other hand, most of the covariance between entrepreneurial intentions and the tendency to be an entrepreneur is accounted for by environmental factors, then such efforts are likely to increase the number of entrepreneurs.

Third, is the genetic effect on the tendency to be an entrepreneur a manifestation of a more general genetic predisposition to occupational choice? It seems unlikely that genetic factors would influence the tendency to become an entrepreneur but not affect the choice of other occupations because the human genome has changed very little in the three thousand years that entrepreneurship has been a vocational option. More plausible is the idea that genetic factors influence the tendency to choose different types of work, one of which is self employment. If this proposition is true, then we should observe a genetic predisposition to other occupational choices in the same context as the choice of self-employment is being made.

Fourth, does the genetic effect found in the previous studies replicate across samples? Most of the findings of genetic effects on the tendency to be an entrepreneur examine the same sample of British twins. These results might be an artifact of the particular sample investigated, suggesting the value of replicating the heritability estimates using a different set of subjects (Campbell and Jackson, 1979).

In this paper, we seek to advance knowledge of genetic effects on entrepreneurship by addressing these four issues through a comparison of identical (MZ) and fraternal (DZ) twins taken from the National Survey of Midlife Development in the United States (MIDUS). ${ }^{1}$ First, we examine a balanced sample of male and female twins to show that genetic effects on the tendency to be an entrepreneur are consistent across gender. Second, we estimate the heritability of the tendency to become self-employed for a sample of U.S. twins to show that these estimates are consistent with the results shown in previous studies for

\footnotetext{
${ }^{1}$ Because MZ twins share 100 percent of their genes while DZ twins share, on average, 50 percent of their segregating genes, differences in the twin concordances for entrepreneurship and occupational choice between the two different types of twins can only be attributed to genetic factors, under the assumption that both types of twins face equal environments.
} 
a sample of UK twins. Third, we show that preference for self-employment in the future what some researchers call entrepreneurial intentions (Zhao et al., 2005; Souitaris et al., 2007) - is heritable, and that the same genetic factors partly influence both entrepreneurial intentions and the tendency to be self-employed. Finally, we show that the tendency to become self-employed is part of a broader heritability of occupational choice.

\section{Theoretical Development}

We argue that there is a substantive genetic component to the tendency to engage in self-employment for both men and women that can be seen through the examination of different samples of twins. This genetic effect operates, in part, by influencing entrepreneurial intentions, and, therefore, is a subset of a wider genetic effect on occupational choice. In the sections below we develop specific hypotheses for each of these effects. We begin with gender differences.

\subsection{Genetic Effects on the Tendency to be Self-Employed}

Using a sample of 870 pairs of monozygotic (MZ) and 857 pairs of same-sex dizygotic (DZ) twins from the United Kingdom, Nicolaou et al. (2008) found that between 37 and 48 percent of the variance in four different measures of the tendency to be an entrepreneur is accounted for by genetic factors. Specifically, these authors found that 48 percent of the difference between people in tendency to be currently self-employed is genetic.

Because genetic differences between the populations of different nations are relatively small, similar genetic effects should exist in the United States. Therefore, we expect that evidence of genetic effects on the tendency to be self-employed would be replicated in a sample of U.S. twins. This argument leads to our first hypothesis:

Hla: Examination of the MIDUS dataset will show that genetic factors have a statistically significant and substantive effect on the propensity of people to be currently engaged in self-employment. 
Genetic effects should not only affect current self-employment but also past selfemployment as well. For many people, self-employment is not a transitory phase, but is a vocation.

The tendency to choose this vocation is partially genetic. Nicolaou et al. (2008) found that genetic factors account for 39 percent of the variance between people in the number of years that they have been self-employed. Because people need to have been selfemployed in the past to be self-employed for a large number of years, this pattern of genetic effects on self-employment duration suggests a genetic effect for past self-employment. This argument leads to our next hypothesis:

H1b: Genetic factors will have a statistically significant and substantive effect on the propensity of people to have engaged in self-employment.

\subsection{Gender Differences in Genetic Effects on the Tendency to be Self-Employed}

Recent studies have shown that genetic factors influence the likelihood that people will be self-employed (Nicolaou and Shane, 2009: Nicolaou et al., 2008). However, these effects have been found from the examination of a largely female sample of British twins. Questions about the generalizability of this finding to men was raised by Zhang et al. (2009), who found substantially greater heritability of entrepreneurship for females than for males. Zhang et al. (2009) have speculated that the difference in the heritability between males and females may arise because environmental factors are much stronger determinants of decision to become an entrepreneur for men than for women. Because women are less likely than men to become entrepreneurs (Shane, 2008), they may not respond as readily to environmental stimuli to become self-employed, even when they are in situations that motivate men to do so (Zhang et al., 2009). The weak effect of environmental factors on the decisions of women to become self-employed might lead genetic effects to manifest themselves in a way not present with men. 
We argue, however, that the genetic effect on self-employment is present for both men and women. There is no evidence that environmental factors affect men so powerfully as to swamp genetic effects on employment decisions. Moreover, there is no evidence that men and women differ substantively on the psychological traits through which genetic effects have been found to operate, or on the tendency to identify opportunities (Shane et al., 2010). Finally, there is no evidence of a biological mechanism through which genetic factors could account for differences between men and women in their tendency to be self-employed. Because of this lack of evidence for a gender-specific explanation for genetic effects on the tendency to be an entrepreneur, we argue that the same genetic effects on self-employment will be present for both genders. The above arguments lead us to the following hypothesis:

H2: $\quad$ There will be no substantive difference in the heritability of self-employment for men and women.

\subsection{Genetic Effects on Entrepreneurial Intentions}

Just as that intentions are a strong predictor of any planned behavior (Ajzen, 1991), entrepreneurial intentions can be a crucial antecedent of future engagement in the entrepreneurial act (Krueger et al., 2000; Souitaris et al. 2007). Simply put, people are more likely to become entrepreneurs if they intend to do so than if they do not. We propose that entrepreneurial intention, or the belief that one will engage in entrepreneurship at some point in the future, exhibits a genetic predisposition.

Entrepreneurial intentions are partially the result of positive attitudes towards the vocation (Souitaris et al., 2007). People who believe that entrepreneurship is a desirable occupation are more likely to plan to become entrepreneurs than people who think that the profession is undesirable.

The association between positive attitudes toward entrepreneurship and entrepreneurial intentions make entrepreneurial intentions likely to have a genetic component. Many attitudes are partly heritable (Eaves et al., 1989; Eaves et al., 1999; Olson et al., 2001 
Just as there is a genetic effect toward holding a positive attitude toward jobs at employers that emphasize safety or job security, we expect that there will be a genetic effect toward holding a positive attitude toward entrepreneurship. Moreover, we expect genetic factors to influence entrepreneurial intentions, just as they influence intentions to select employers that have cultures consistent with one's attitudes and beliefs. This argument leads to our next hypothesis:

H3a: Genetic factors will have a substantive and statistically significant effect on entrepreneurial intentions.

The same genetic factors that make people more likely to develop entrepreneurial intentions will also influence their tendency to be self-employed. Stronger entrepreneurial intentions should increase the odds that a person becomes self-employed because intentions affect behavior (Ajzen, 1991). As a result, any genetic effect on the tendency to become selfemployed should operate, at least in part, through entrepreneurial intentions. For instance, genetic differences might make some people more predisposed to develop entrepreneurial intentions than other people. Because people with entrepreneurial intentions are more likely than those without such intentions to go into business for themselves, these genetic predispositions toward entrepreneurial intentions will increase the odds that people become self-employed. This argument leads to our next hypothesis:

H3b: The same genetic factors that influence entrepreneurial intentions will also influence the tendency to be self-employed.

\subsection{Genetic Effects on Occupational Choice}

Genetic effects on the tendency to become self-employed are part of a larger tendency of genes to affect occupational choice. Because the human genome has changed very little in 
the three thousand years that entrepreneurship has been a vocational option, it seems unlikely that entrepreneurship-specific genetic effects exist. Rather, whatever genetic factors lead people to choose self-employment over wage employment likely also influence the choice of other occupations.

Several streams of research suggest that genetic factors affect occupational choice in general. Prior studies have shown substantive heritability for vocational interests (Moloney et al., 1991; Betsworth et al., 1994). These studies indicate that genes influence whether people want to become doctors, commodities traders, ranchers, firemen, automobile salesmen, or any number of other occupations (Carter, 1932), across a number of different ways that researchers measure work interests, from the actual jobs themselves, to skills-based occupational groupings, to type of work that people describe liking (Vandenberg and Stafford, 1967). Furthermore, these results have been found in studies that use all of the major vocational instruments employed by researchers, including the Minnesota Vocational Interest Inventory, the Jackson Vocational Interest Survey, and the Strong Vocational Interest Blank (Maloney et al., 1991; Arvey and Bouchard, 1994), and that employ both twin and adoption designs (Ellis and Bonin, 2003; Grotevant et al., 1977).

Some studies of genetic effects on work interests even show genetic effects on preferences for the very job categories used by human resource experts in vocational training assessments to tell people what jobs they are best suited for, such as the Holland vocational testing instrument (Holland, 1985). These studies show that identical twins, whether raised together or apart, tend to have much more similar job interests than their fraternal counterparts (Bouchard et al., 1990); and adopted children are much more likely to want to work in the same professions as their biological parents than in those of their adoptive parents (Betsworth et al., 1994). Moreover, prior studies show that genetic factors influence people's interest in several dimensions of business, from managing people to merchandising to sales to finance (Moloney et al., 1991; Betsworth et al, 1994). Because vocational interests are associated with occupational choice, it is plausible that occupational choice also exhibits a genetic predisposition. 
Moreover, prior research shows that genetic factors influence people's choice of jobs. Tambs et al. (1989) found a genetic effect for the choice between unskilled labor, skilled labor, non-manual labor and professional work. Genes also affect the organizational values and work climates that people prefer (Bouchard et al., 2004; Keller et al., 1992). Genetic factors even influence job and occupational change (McCall et al, 1997).

Furthermore, people with certain personality and cognitive characteristics tend to be overrepresented in certain jobs than in others (e.g. sales personnel are disproportionately likely to be extraverted while actuaries are disproportionately strong at mathematics). Research has found that most personality characteristics and cognitive abilities are heritable (e.g. Loehlin, 1992; Plomin et al., 2008). Therefore, occupational choice may be influenced by genetics through genetic covariation between personality or cognitive abilities and occupational choice. These arguments lead to the following hypothesis:

H4: Genetic factors will account for part of the variance in occupational choices other than the choice to be self-employed.

\section{Methodology}

\subsection{Twin Studies}

"Twins constitute a compelling natural experiment" (Evans et al., 2003, p. 432) that can be used to examine genetic effects on human behavior. Just as a laboratory experiment contrasts the results of an experimental sample to that of a control sample to identify the effect of an independent variable that is being manipulated, so does a twin study. The twin study design is more akin to a natural experiment than a laboratory experiment because the causal factor occurs naturally and is not manipulated by the investigator. The natural experimental design (Plomin et al. 2008, p. 75; Rutter, 2007) comes about because there are two types of twins - MZ twins that share 100 percent of their genes and DZ twins that share, on average, 50 percent of their segregating genes. Under the assumption that environmental conditions treat $\mathrm{MZ}$ and $\mathrm{DZ}$ twins equally, differences in the concordances between the 
behavior of $\mathrm{MZ}$ and $\mathrm{DZ}$ twins provides information about the genetic component of that behavior. If MZ twins show higher concordances for self-employment, occupational choice or entrepreneurial intention than DZ twins, then these behaviors display a genetic predisposition. If, on the other hand, MZ twin concordances for these behaviors are similar to those of DZ twins, then there is no evidence of a genetic predisposition.

For the equal environments assumption to fail to hold, MZ and DZ twins must experience different environments, and this difference in treatment must influence the variable under investigation (in our case, self-employment, occupational choice, and entrepreneurial intentions). While we cannot directly test this assumption with our data, numerous studies using different methodologies have examined it, all of which have confirmed its robustness (Scarr and Carter-Saltzman, 1979; Kendler, 1983; Kendler et al., 1994; Hettema et al., 1995; Kendler and Prescott, 2006; Plomin et al., 2008). For example, studies have shown that some parents tend to individualize their MZ twins, while others tend to promote the similarity between their DZ twins. The end result is little systematic difference between MZ and DZ twins. Furthermore, many parents often make wrong judgments about the zygosity status of their twins and raise MZ twins as DZ twins and vice versa; and research has shown that in such cases it is actual, not perceived zygosity that influences the degree of behavioral similarity between the co-twins (Scarr and Carter-Saltzman, 1979). Therefore, we make the equal environments assumption in our analysis.

\subsection{Sample}

The data for the analysis were drawn from the twin sample of the National Survey of Midlife Development in the United States (MIDUS). For this survey, a representative national sample of approximately 50,000 people was initially screened for the presence of a twin. Those twins willing to participate in the study were then asked to provide their contact details and the contact information for their co-twins.

The surveyors then collected data from both twins on a wide range of topics, from employment to health to personal interests, through both interviews and mailed surveys. The 
portions of the interviews and questionnaires that discussed self-employment and occupational choice were examined here.

To conduct a twin study, we need to identify which pairs of twins were MZ and DZ twins. Researchers identified zygosity using standardized questions and through DNA samples. Of the 998 twin pairs that were recruited in the study, 910 pairs were of discernible zygosity. As we can only use twins whose zygosity is known, we excluded the 88 pairs of twins of unknown zygosity.

To compare identical and fraternal twins on a behavior of interest, typically MZ and same sex DZ twins are compared (because DZ twins can be of opposite sexes but MZ twins cannot). Therefore, we excluded opposite-sex DZ twins from further analysis. In the rare cases where there were multiple twin pairs from the same family, one twin pair was chosen at random. These adjustments left us with the 347 pairs of MZ and 303 pairs of same sex DZ twins, on which our analysis was based.

\subsection{Measures}

Current self-employment. We examined the respondent's employment status to determine if the person was self employed. The variable was coded as 1 if the individual was currently self-employed and 0 otherwise (Amit et al., 1995; Evans and Leighton, 1989; Burke et al., 2000; Parker, 2004).

Past self-employment. We examined the respondent's employment status ten years earlier to measure past self-employment. This variable was coded as 1 if the individual was self-employed ten years earlier and 0 otherwise.

Occupational choice. To measure occupational choice, we identified three different occupations (using the 1980 classification of occupational codes) for which sufficient numbers of respondents had the occupation. These were manager, ${ }^{2}$ salesperson, and teacher.

Entrepreneurial intentions. To measure entrepreneurial intentions we examined whether an individual reported the intention to be self-employed in ten years time. This

\footnotetext{
${ }^{2}$ An individual was coded as being a manager if he/she was a chief executive, financial manager, personnel and labor relations manager, purchasing manager, manager, administrator or supervisor.
} 
variable was coded as 1 if the individual indicated an intention to be self-employed ten years

in the future and 0 otherwise.

\subsection{Structural equation modeling}

Quantitative genetics analysis enables us to estimate the relative proportions of genetic and environmental components to the phenotypic variance in self-employment, occupational choice and entrepreneurial intentions. In quantitative genetic analysis, three unobservable components are combined additively to explain phenotypic variance: additive genetics effects (abbreviated by A), shared environmental factors ${ }^{3}$ (abbreviated by C), and non-shared environmental factors (abbreviated by E), (Neale and Cardon, 1992; Sham et al., 1994; Plomin et al., 2008).

Figure 1 shows the path diagrams underlying the structural equation modeling. ${ }^{5}$ The boxes in the diagrams represent the observed variables (self-employment, occupational choice, and entrepreneurial intentions) and the circles represent the three latent variables that the model estimates: genetic effects (A), shared environmental effects (C), and non-shared environmental effects (E). The curved two-headed arrows represent the covariances between the latent factors. Based on the principles of twinning and genetic segregation (i.e. that $\mathrm{MZ}$

\footnotetext{
${ }^{3}$ Shared environmental factors are "the factors that are shared by family members and make them more similar, such as parental rearing styles...." (Kendler and Prescott, 2006, p. 40).

${ }^{4}$ Non-shared environmental factors are the environmental effects that are unique to an individual (Neale and Cardon, 1992; Sham et al., 1994; Plomin et al., 2008).

5 Structural equations modeling is the most widely used statistical technique for separating genetic from environmental variance in behavior (Cherny et al., 1992; Sham, 1998; Kendler and Prescott, 2006; Plomin et al., 2008). Although regression analysis and other methodologies for the analysis of twins have been proposed (Defries and Fulker, 1985; Sham et al., 1994), there are significant advantages in using the more general framework of structural equation modeling (Martin and Eaves, 1975, Sham et al., 1994; Sham, 1998). First, the hypothetical causal relationships which are made explicit in a structural equation model are only implicit in the regression analyses (Sham, 1998). Consequently, if we had simply regressed the behaviors of twin 1 on the behaviors of twin 2 to see if there was a differential risk between MZ and DZ twins, this would only provide a test of genetic aetiology, not latent heritability. To estimate latent heritability, we need structural equation modeling which assumes that all polygenes act in an independent additive manner to provide a hypothetical normal distribution of risk underlying a binary trait. Second, structural equations permit the comparison of various sub-models that are nested in the original model, which enable the identification of the most parsimonious model (Bulik et al., 2000). Third, the regression approach usually requires constrained estimation to avoid nonsensical estimates (e.g. negative proportions of variance or estimates exceeding unity) (Cyphers et al., 1990). Fourth, regressions may face violations of the homoskedasticity assumption, arising from the fact that DZ twins are expected to have a greater residual variance than MZ twins, in the presence of a genetic component (Sham, 1998).
} 
twins share all their genes and DZ twins share half of their segregating genes), the covariance between the additive genetic components (A) is set at 1.00 for MZ pairs and 0.5 for DZ pairs. The covariance between the shared environmental components $(\mathrm{C})$ is set at 1.00 for both sets of twins. The unique environmental components (E) are, by definition, not correlated between the twin pairs.

\section{INSERT FIGURE 1 ABOUT HERE}

The models that we use are represented by the structural equations below:

$\Omega_{i x}=a A_{i x}+c C_{i x}+e E_{i x}$

$V_{\Omega}=a^{2}+c^{2}+e^{2}=1$

where $\Omega$ is the phenotype of the $i$ th individual in the $x$ th pair $(i=1,2 ; x=1 \ldots n$; all variables scaled as deviations from zero), and $V_{\Omega}$ is the total phenotypic variance in the population representing the sum of additive genetic $\left(a^{2}\right)$, common environmental $\left(c^{2}\right)$ and unique environmental variance $\left(e^{2}\right)$. These models produce the following predicted variancecovariance matrices for the ACE models:

Cov MZ

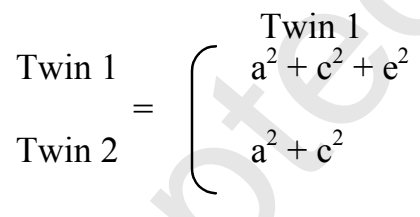

Cov DZ $\quad \begin{aligned} & \text { Twin } 1 \\ & \text { Twin 2 }\end{aligned}=\left(\begin{array}{l}\text { Twin } 1 \\ \mathrm{a}^{2}+\mathrm{c}^{2}+\mathrm{e}^{2} \\ 1 / 2 \mathrm{a}^{2}+\mathrm{c}^{2}\end{array}\right.$ $\left.\begin{array}{l}\text { Twin } 2 \\ a^{2}+c^{2} \\ a^{2}+c^{2}+e^{2}\end{array}\right)$

Twin 2

$\left.\begin{array}{l}1 / 2 a^{2}+c^{2} \\ a^{2}+c^{2}+e^{2}\end{array}\right\}$

The degree to which the same genetic factors affect both entrepreneurial intentions and the tendency to be self-employed is measured through bivariate genetic analysis (the path diagram is illustrated in figure 2). Bivariate genetic analysis allows the covariance between entrepreneurial intentions and the tendency to be self-employed to be disentangled into that due to additive genetic, shared environmental, and non-shared environmental effects (Kuntsi et al., 2004; Rice et al., 2004; Singer et al., 2006). The variance covariance matrix that we estimate for the MZ twins is shown in Figure 2, while the variance covariance matrix for the 
DZ twins is shown in Figure 2 ( $\Phi$ stands for entrepreneurial intentions while $\Psi$ symbolizes the tendency to be self-employed).

\section{INSERT FIGURES 2 AND 3 ABOUT HERE}

In these figures $r_{A}, r_{C}$, and $r_{E}$ represent the genetic correlation, the shared environmental correlation and the unique environmental correlation, respectively. The genetic correlation, $r_{A}$, indicates the extent to which the genetic influences on entrepreneurial intentions overlap with those on the tendency to be self-employed, irrespective of their individual heritabilities. For example, a genetic correlation of 1 would mean that all genetic influences on entrepreneurial intentions also impact on the tendency to be self-employed (Plomin et al., 2008).

We use maximum likelihood estimates to generate the parameters, and estimate the fit of the model using a chi-square goodness of fit statistic. A non-significant chi-square is indicative of a good model fit. We ran a series of nested sub-model comparisons and utilized the Akaike's Information Criterion (Akaike, 1987) and the Root Mean Square Error of Approximation (RMSEA) to select the best fitting model (Betsworth et al., 1994).

We utilized liability threshold models in which the presence or absence of selfemployment, occupational choice or entrepreneurial intentions is predicated on the assumption of an underlying continuous distribution, and the expression of a "phenotype" occurs when the liability is above a threshold value (Sham, 1998). The status of the twins is summarized by $K_{i x}$, where the first subscript indicates the status of twin 1 (e.g. $1=$ manager; 0 $=$ not a manager) and the second subscript indicates the status of twin 2 . The log likelihood of a twin pair is then given by:

$$
\ln L=\sum_{i=0}^{1} \sum_{x=0}^{1} \mathrm{~K}_{i x} \ln \left(p_{i x}\right)
$$

The probabilities $p_{i x}$ are determined by numerical integration of the bivariate normal distribution over the liabilities for twin 1 and twin 2 (bounded by the appropriate thresholds). For example, the probability that both twins are managers is given by: 
$p_{11}=\int_{\Delta_{1} \Delta_{2}}^{\infty} \int_{\Delta_{2}}^{\infty} \Gamma\left(L_{1}, L_{2} ; 0, \Sigma\right) d L_{1} d L_{2}$, where $\Gamma$ is the bivariate normal probability density function, $L_{1}$ and $L_{2}$ are the liabilities for twins 1 and 2 respectively, $\Sigma$ is the correlation matrix of the two liabilities, and $\Delta_{1}$ and $\Delta_{2}$ are the threshold values for twins 1 and 2 respectively. Similarly, the probability that only one of twins is a manager is given by:

$$
p_{10}=p_{01}=\int_{\Delta_{1}}^{\infty} \int_{-\infty}^{\Delta_{2}} \Gamma\left(L_{1}, L_{2} ; 0, \Sigma\right) d L_{1} d L_{2}
$$

\section{Results}

Because the focus of twin studies is on the concordance between pairs of $\mathrm{MZ}$ and $\mathrm{DZ}$ twins, differences between $\mathrm{MZ}$ and $\mathrm{DZ}$ twins in the level of the phenotypes investigated can make interpretation difficult. However, when we compared MZ and DZ twins on current self-employment, past-self-employment, occupational choice, and entrepreneurial intentions, we found no statistically significant differences between $\mathrm{MZ}$ and $\mathrm{DZ}$ twins. That is, $\mathrm{MZ}$ and DZ twins are no more or less likely than the other type of twin to display these phenotypes.

Table 1 shows the results of the genetic modeling analysis to predict whether the individual is currently self-employed. The chi-square goodness of fit test, the Root Mean Square Error of Approximation (RMSEA) and Akaike information criterion (AIC) all showed that the best-fitting model included additive genetic (A) and non-shared environmental factors (AE model). Specifically, the results showed that genetic factors accounted for 48 percent of the variance in current self-employment. This heritability is identical to that found for selfemployment for a study of British twins (Nicolaou et al., 2008), and thus provides support for hypothesis 1a. The heritability of self employment is substantive regardless of the sample used to examine it.

\section{INSERT TABLE 1 ABOUT HERE}

Table 2 shows the results of the genetic modeling analysis for past self-employment. The AE model was again the best-fitting model, with a heritability estimate of 0.64 . This 
result provides support for hypothesis $1 \mathrm{~b}$. Self-employment is highly heritable, whether measured as past or current self-employment.

\section{INSERT TABLE 2 ABOUT HERE}

The results presented above combined both the male and female twins in the same sample, suggesting that genetic effects on self-employment were substantive for both men and women. To ensure that genetic effects on self-employment were present for males, we reestimated our models using a male-only sample. Table 3 shows the results of the best-fitting AE models for all variables for the male-only sample. The heritability estimates for current and past self-employment were 0.59 and 0.70 respectively, formally indicating support for hypothesis 2. Genetic effects on self employment exist for men as well as for women.

\section{INSERT TABLE 3 ABOUT HERE}

Table 4 shows the results of the genetic modeling analysis for entrepreneurial intentions. The AE model was the best fitting model, with a heritability estimate of 0.42 . This result provides support for hypothesis $3 \mathrm{a}$. Genetic factors have a substantive and statistically significant effect on entrepreneurial intentions.

\section{INSERT TABLE 4 ABOUT HERE}

We examined whether a common genetic factor influences both the propensity of people to be currently engaged in self-employment and to express entrepreneurial intentions, as well the propensity of people to have engaged in self-employment and to express entrepreneurial intentions. Table 5 shows the cross-twin-cross-trait correlations for the propensity of people to have engaged in self-employment and express entrepreneurial intentions. The cross-trait cross-twin correlations for MZ twins were 0.24 and 0.15 . Similarly, the cross-trait cross-twin correlations for DZ twins were 0.11 and 0.10 . The cross-trait crosstwin correlations are greater for $\mathrm{MZ}$ twins than for $\mathrm{DZ}$ twins suggesting that genetic factors are contributing to the phenotypic correlation between the propensity of people to have engaged in self-employment and to express entrepreneurial intentions. In fact, the bivariate genetic analysis indicates that 57 percent of the phenotypic correlation between the propensity of people to have engaged in self-employment and to express entrepreneurial intentions is 
accounted for by genetic influences that are common to the two $\left(\mathrm{r}_{\mathrm{A}}=0.66\right)$. Similarly, the analysis showed that 39 percent of the phenotypic correlation between the propensity of people to be currently engaged in self-employment and to express entrepreneurial intentions is accounted for by common genetic factors $\left(\mathrm{r}_{\mathrm{A}}=0.85\right)$. These results provide support for hypothesis $3 \mathrm{~b}$. The same genetic factors influence both entrepreneurial intentions and the tendency to be self-employed.

\section{INSERT TABLE 5 ABOUT HERE}

Tables 6,7 and 8 show the results for the heritability of the three different occupational choices for which a large enough sample was available to investigate: manager, sales person, and teacher. The results show that being a manager, salesperson or teacher are all partially genetic, displaying heritability estimates of $0.30,0.46,0.43$ respectively. These results support hypothesis 4: Genetic factors account for part of the variance in occupational choice.

\section{INSERT TABLES 6, 7 AND 8 ABOUT HERE}

\section{Discussion}

We applied quantitative genetics techniques to a sample of 347 pairs of MZ and 303 pairs of DZ twins taken from the MIDUS database to examine the influence of genetic factors on variation in the tendency to be self-employed, with the goal of addressing several questions that have been raised about previous work in this area. We found substantial heritability for the tendency to be self-employed currently, and ten years prior, for a U.S. sample of twins, with no influence of the shared environment. We also found that this heritability is substantive for male as well as female twins. Moreover, we found that the intention to be self-employed in the future is heritable, and that a common genetic factor influences both the expression of entrepreneurial intentions and the tendency to be selfemployed. Finally, we found that the choice to be a teacher, manager or salesperson was also heritable. 


\subsection{Limitations}

Like all studies, this one is not without limitations. Our study's validity depends on support for the equal environments assumption. This assumption holds that MZ twins are not treated more similarly than DZ twins with respect to the phenotype under study. In our case, this assumption would be violated if the family or non-family environment treated MZ twins more similarly than DZ twins with respect to self-employment, entrepreneurial intentions, and occupational choice. While we have no way of verifying the validity of the assumption for our data, we know of no evidence, anecdotal or statistical, that suggests that the environment treats $\mathrm{MZ}$ twins more similarly than DZ twins with respect to the phenotypes we examine. Nevertheless, we acknowledge that our inability to "show" support for the assumption is a limitation of the paper.

In addition, our results are only a first step toward explaining how our genes influence entrepreneurial behavior. Behavioral genetics studies, such as this one, cannot identify the specific genes that affect occupational choice. We must await future research to identify what those genes are, to find out how many of them are at work, to learn how they interact; and to identify the mechanisms through which they operate.

\subsection{Implications}

Our study contributes to a new literature that considers a "biosocial" model of entrepreneurial behavior (White et al., 2006, 2007; Nicolaou and Shane, 2009; Nicolaou et al., 2008, Zhang et al., 2009). This literature attempts to better explain entrepreneurial behavior by bringing together sociological and biological explanations. By replicating previous findings for the heritability of self-employment for a new sample and by demonstrating that the genetic effect on the tendency to engage in this activity for both men and women, our study provides additional empirical support for the assertion that there is a genetic component to entrepreneurial behavior.

Moreover, our study extends the biosocial model by testing for whether genetic effects on self-employment are mediated by entrepreneurial intentions. Consistent with 
research on the effect of attitudes on behavior, our study shows that the desire to be an entrepreneur is heritable, and that one mechanism through which genes affect the tendency to be an entrepreneur lies in genetic differences in the predisposition to develop entrepreneurial intentions.

Furthermore, our study contributes to a broader literature on the heritability of work interests and occupational choice. Just as we find that the choice to be self-employed is heritable, so do we find that the choices to be a teacher, manager and sales person are also heritable. Thus, our study links findings on genetic effects on entrepreneurship to genetic effects on other occupational variables, such as vocational interests (Moloney et al., 1991; Betsworth et al., 1994), work values (Keller et al., 1992), job satisfaction (Arvey et al., 1989) and occupational change (McCall et al., 1997).

We believe that the heritability of occupational choice is of significant interest to entrepreneurship scholarship because it can help determine whether the genetic predisposition to entrepreneurship is part of a more general genetic predisposition to occupational choice. For example, future research could investigate the extent to which the genes that influence the tendency to become a manager are also the same genes that influence the tendency to become an entrepreneur, which would help us to understand whether entrepreneurship and management are closely related or vastly different occupations. Moreover, future work may attempt to investigate whether a common genetic factor influences many occupational choices, suggesting that the genetic predisposition to entrepreneurship is just a specific case of a more general genetic predisposition to occupational choice.

From a practical perspective, it is important to emphasize that our results do not suggest that genes determine entrepreneurship or occupational choice, but that genetic factors merely predispose some people to choose these occupations. Entrepreneurship and occupational choice are not hard-wired patterns of behavior, and environmental factors account for most of the variance in these variables. That is, genetic factors matter, but only in a probabilistic sense, and less than environmental factors. Moreover, it is extremely unlikely that a specific gene would code for a particular occupational choice. Rather, genetic factors 
are likely to affect occupational choice by (i) influencing individual differences that are associated with occupational choices, and (ii) through selection of people into different environments. ${ }^{6}$

This might occur through the tendency of the heritability of occupational choices to fall into clusters. ${ }^{7}$ Certain occupations - e.g. being an engineer or an actuary - that require technical skills could be influenced by similar genes, whereas other occupations - such as being a designer or an artist - could be influenced by other genes that spawn a more creative and artistic slant. Multivariate genetic analyses could be used to investigate the genetic correlation between various occupations that fall in the same "cluster."

Finally, we found that all of the environmental effects on the occupational choices that we examined were of the non-shared type. This finding suggests the importance of factors outside the family, such as work environment and external career advice, in influencing the likelihood of becoming self-employed or choosing certain occupations.

\footnotetext{
6 The latter phenomenon is called gene-environment correlations and refers to the non-random distribution of the environment among people of different genetic make-up (Neale and Maes, 2002; Plomin et al., 2008).

${ }^{7}$ We are grateful to an anonymous reviewer for this point.
} 


\section{References}

Ajzen, I., 1991. The theory of planned behavior. Organizational Behavior and Human Decision Processes 50, 179-211.

Akaike, H., 1987. Factor Analysis and AIC. Psychometrika 52, 317-332.

Amit, R., Muller, E., Cockburn, I., 1995. Opportunity costs and entrepreneurial activity. Journal of Business Venturing 10, 95-106.

Arvey, R., and Bouchard, T., 1994. Genetics, twins, and organizational behavior. Research in Organizational Behavior 16, 47-82.

Arvey, R., Bouchard, T., Segal, N., Abraham, L., 1989. Job satisfaction: Environmental and genetic components. Journal of Applied Psychology 74, 187-192

Betsworth, D, Bouchard, T., Cooper, C., Grotevant, H., Hansen, J., Scarr, S., Weinberg, R., 1994. Genetic and environmental influences on vocational interests assessed using adoptive and biological families and twins reared together and apart. Journal of Vocational Behavior 44, 263-278.

Bouchard, T., Lykken, D., McGue, M., Segal, N., Tellegen, A., 1990. Sources of human psychological differences: The Minnesota study of twins reared apart. Science, 250, 223-228.

Bouchard, T., Segal, N., Tellegen, A., McGue, M., Keyes, M., Krueger, R., 2004. Genetic influence on social attitudes: Another challenge to psychology from behavior genetics. In: DiLalla, L. (Ed.) Behavior Genetics Principles. Washington, D.C.: American Psychological Association, 89-104

Bulik, C. M., Sullivan, P. F., Wade, T. D., Kendler, K. S., 2000. Twin studies of eating disorders. International Journal of Eating Disorders 27, 1-20.

Burke, A.E., FitzRoy, F. R., Nolan, M. A., 2000. When less is more: distinguishing between entrepreneurial choice and performance. Oxford Bulletin of Economics and Statistics $62,567-587$. 
Campbell, K., Jackson, T., 1979. The role of and need for replication research in social psychology. Replications in Social Psychology 1, 2-14.

Carter, H., 1932. Twin similarities in occupational interests. The Journal of Educational Psychology 23, 641-655.

Cherny, S. S., DeFries, J. C., Fulker, D. W., 1992. Multiple regression of twin data: A modelfitting approach. Behavior Genetics 22, 489-497.

Cyphers, L. H., Phillips, K., Fulker, D. W., Mrazek, d. A., 1990. Twin temperament during the transition from infancy to early childhood. Journal American Academy Child Adolescence Psychiatry 29, 392-397.

DeFried, J. C., Fulker, D. W., 1985. Multiple regression analysis of twin data. Behavior Genetics 15, 467-473.

Eaves, L. J., Eysenck, H. J., Martin, N. G., 1989. Genes, culture, and personality: An Empirical Approach. London: Academic Press.

Eaves, L., Heath, A., Martin, N., Maes, H., Neale, M., Kendler, K., Kirk, K., Corey, L., 1999 Comparing the biological and cultural inheritance of personality and social attitudes in the Virginia 30,000 study of twins and their relatives. Twin Research 2, 62-80.

Ellis, L., Bonin, S., 2003. Genetics and occupation-related preferences. Evidence from adoptive and non-adoptive families. Personality and Individual Differences 35, 929937.

Evans, A., Van Baal, G. C. M., McCarron, P., DeLange M.; Soerensen T. I., De Geus E. C., Kyvik K., Pedersen, N. L., Spector, T. D., Andrew, T., Patterson C., Whitfield, J. B., Zhu G., Martin, N. G., Kaprio, J., Boomsma, D. I., 2003. The genetics of coronary heart disease: the contribution of twin studies. Twin research: the official journal of the International Society for Twin Studies 6, 432-41.

Evans, D., Leighton, L., 1989. Some empirical aspects of entrepreneurship. American Economic Review 79, 519-535.

Grotevant, H., Scarr, S., Weinberg, R., 1977. Patterns of interest similarity in adoptive and biological families. Journal of Personality and Social Psychology 35, 667-676; 
Hettema, J. M., Neale, M. C., Kendler, K. S., 1995. Physical similarity and the equal environment assumption in twin studies of psychiatric disorders. Behavior Genetics $25,327-335$.

Keller, L. M., Bouchard, T. J., Arvey, R. D., Segal, N. Dawis, R. V., 1992. Work values: Genetic and environmental influences. Journal of Applied Psychology 77, 79-88.

Kendler, K. S., 1983. Overview: A current perspective on twin studies of schizophrenia. American Journal of Psychiatry 140, 1413-1425.

Kendler, K. S., Neale, M. C., Kessler, R. C., Heath, A. C., Eaves, L. J., 1994. Parental treatment and the equal environments assumption in twin studies of psychiatric illness. Psychological Medicine 24, 579-590.

Kendler, K. S., Prescott, C. A., 2006. Genes, Environment and Psychopathology. New York: Guilford Press.

Krueger, N. F., Reilly, M. D., Carsrud, A. L., 2000. Competing models of entrepreneurial intentions. Journal of Business Venturing 15, 411-432.

Kuntsi, J., Eley, T. C., Taylor, A., Hughes, C., Asherson, P., Caspi, A., Moffitt, T. E., 2004. Co-occurrence of ADHD and low IQ has genetic origins. American Journal of Medical Genetics Part B. 124B, 41-47.

Loehlin, J., 1992. Genes and the Environment in Personality Development. Newbury Park, CA: Sage Publications.

Martin, N. G., Eaves, L. J., 1977. The genetic analysis of covariance structure. Heredity 38, 79-95.

McCall, B., Cavanaugh, M., Arvey, R., 1997. Genetic influences on job and occupational switching. Journal of Vocational Behavior 50, 60-77.

Moloney, D. P., Bouchard, T. J., Segal, N. L., 1991. A genetic and environmental analysis of the vocational interests of monozygotic and dizygotic twins reared apart. Journal of Vocational Behavior 39, 76-109. 
Neale, M. C., Maes, H. H. M., 2002. Methodology for Genetic Studies of Twins and Families. Dordrecht, Netherlands: Kluwer Academic Publishers.

Neale, M., Cardon, L., 1992. Methodology for Genetic Studies of Twins and Families. Dordecht: Klewer Academic Publishers.

Nicolaou, N., Shane, S., 2009. Can genetic factors influence the likelihood of engaging in entrepreneurial activity? Journal of Business Venturing 24, 1-22.

Nicolaou, N., Shane, S., Cherkas, L., Hunkin, J., Spector, T., 2008. Is the tendency to engage in entrepreneurship genetic? Management Science, 54, 167-179.

Olson, J. M, Vernon, P. A., Harris, J. A., Jang, K . L., 2001. The heritability of attitudes: A study of twins. Journal of Personality and Social Psychology 80, 845-860.

Parker, S. C., 2004. The Economics of Self-Employment and Entrepreneurship. Cambridge: Cambridge University Press.

Plomin, R., DeFries, J. C., McClearn, G. E., McGuffin, P., 2008. Behavioral Genetics. $5^{\text {th }}$ Edition. New York: Worth Publishers.

Rice, F., van den Bree, M. B. M.,Thapar, A., 2004. A population-based study of anxiety as a precursor for depression in childhood and adolescence. BMC Psychiatry 4, 43.

Rutter, M., 2007. Proceeding from observed correlation to causal inference: The use of natural experiments. Perspectives on Psychological Science 2, 377-395.

Scarr, S., Carter-Saltzman, L., 1979. Twin method: Defense of a critical assumption. Behavior Genetics 9, 527-542.

Sham, P. C., Walters, E. E., Neale, M. C., Heath, A. C., MacLean, C. J., Kendler, K. S., 1994. Logistic regression analysis of twin data: estimation of parameters of the multifactorial liability-threshold model. Behavior Genetics 24, 229-238.

Sham, P., 1998. Statistics in Human Genetics. London, UK: Arnold.

Shane, S., 2003. A General Theory of Entrepreneurship: The Individual-Opportunity Nexus, Aldershot, UK: Edward Elgar Publishing.

Shane, S., 2008. Illusions of Entrepreneurship: The Costly Myths that Entrepreneurs, Investors, and Policy Makers Live By. New Haven, CT: Yale University Press. 
Shane, S., Nicolaou, N., Cherkas, L., Spector, T. D., 2010. Do openness to experience and recognizing opportunities have the same genetic source? Human Resource Management 49, 291-303.

Singer J. J., MacGregor A. J., Cherkas L. F., Spector T. D., 2005. Where did I leave my keys? A twin study of self-reported memory ratings using the multifactorial memory questionnaire. Twin Research Human Genetics 8, 108-12.

Souitaris, V., Zerbinati, S., Al-Laham, A., 2007. Do entrepreneurship programmes raise entrepreneurial intention of science and engineering students? The effect of learning, inspiration and resources. Journal of Business Venturing 22, 566-591.

Tambs, K., Sundet, J. M., Magnus, P., Berg, K., 1989. Genetic and environmental contributions to the covariance between occupational status, educational attainment and IQ: a study of twins. Behavior Genetics 19, 209-222.

Vandenberg, S., Stafford, R., 1967. Hereditary influences on vocational preferences as shown by scores of twins on the Minnesota vocational interest inventory. Journal of Applied Psychology 51, 17-19.

White, R., Thornhill, S., Hampson, E., 2006. Entrepreneurs and evolutionary biology: The relationship between testosterone and new venture creation. Organizational Behavior and Human Decision Processes 100, 21-34.

White, R., Thornhill, S., Hampson, E., 2007. A biosocial model of entrepreneurship: the combined effects of nurture and nature. Journal of Organizational Behavior 28, 451466.

Zhang, Z., Zyphur, M., Narayanan, J., Arvey, R., Chaturvedi, S., Avolio, B.., Lichtenstein, B., Larsson, G., 2009. The Genetic Basis of Entrepreneurship: Effects of Gender and Personality. Organizational Behavior and Human Decision Processes 110, 93-107.

Zhao, H., Hills, G. E., Seibert, S. E., 2005. The mediating role of self-efficacy in the development of entrepreneurial intentions. Journal of Applied Psychology 90, 12651272. 
Figure 1: Path diagrams for basic twin model
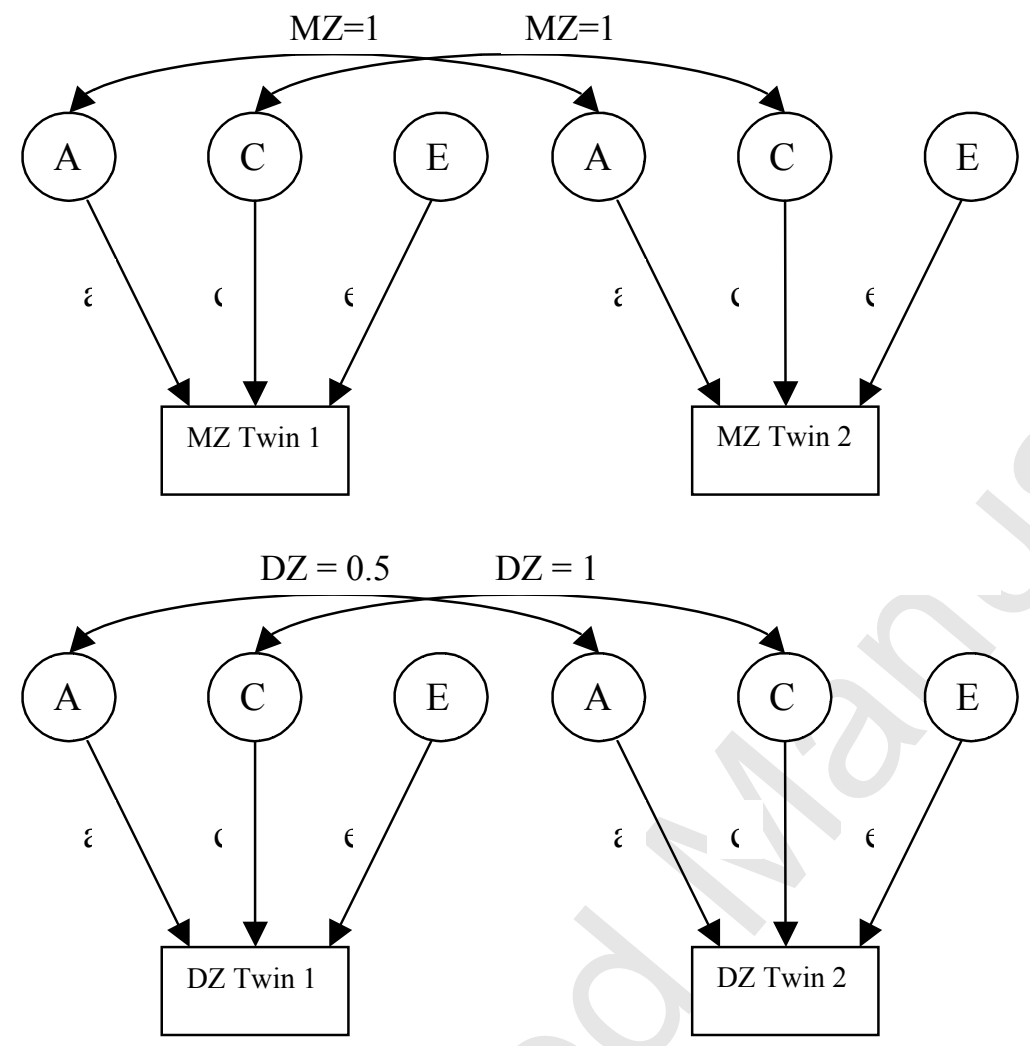
Figure 2. The variance covariance matrix for the MZ twins.

\section{Twin 1}

Entrepreneurial

Intentions $(\Phi)$

Twin 1

Entrepreneurial $\quad a_{\Phi}^{2}+c_{\Phi}^{2}+e_{\Phi}^{2}$

Intentions $(\Phi)$

Twin 2

Entrepreneurial

$a_{\Phi}^{2}+c_{\Phi}^{2}$

$a_{\Phi}^{2}+c_{\Phi}^{2}+e_{\Phi}^{2}$

Intentions $(\Phi)$

Twin 1

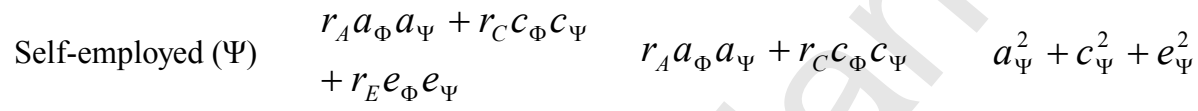

Twin 2

$\begin{array}{ll}\text { Self-employed ( } \Psi) & r_{A} a_{\Phi} a_{\Psi}+r_{C} c_{\Phi} c_{\Psi} \\ & \begin{array}{l}r_{A} a_{\Phi} a_{\Psi}+r_{C} c_{\Phi} c_{\Psi} \\ +r_{E} e_{\Phi} e_{\Psi}\end{array} \quad a_{\Psi}^{2}+c_{\Psi}^{2}\end{array} \quad a_{\Psi}^{2}+c_{\Psi}^{2}+e_{\Psi}^{2}$
Twin $1 \quad$ Twin 2

Self-employed ( $\Psi) \quad$ Self-employed ( $\Psi)$ 
Figure 3. The variance covariance matrix for the DZ twins.

Twin $1 \quad$ Twin 2

Entrepreneurial Entrepreneurial

Intentions $(\Phi) \quad$ Intentions $(\Phi)$
Twin 1

Self-employed ( $\Psi)$
Twin 2

Self-employed ( $\Psi)$

Twin 1

Entrepreneurial $\quad a_{\Phi}^{2}+c_{\Phi}^{2}+e_{\Phi}^{2}$

Intentions $(\Phi)$

Twin 2

Entrepreneurial

$0.5 a_{\Phi}^{2}+c_{\Phi}^{2} \quad a_{\Phi}^{2}+c_{\Phi}^{2}+e_{\Phi}^{2}$

Intentions $(\Phi)$

Twin 1

Self-employed ( $\Psi)$

$$
\begin{array}{ll}
r_{A} a_{\Phi} a_{\Psi}+r_{C} c_{\Phi} c_{\Psi} & 0.5 r_{A} a_{\Phi} a_{\Psi}+r_{C} c_{\Phi} c \\
+r_{E} e_{\Phi} e_{\Psi} & a_{\Psi}^{2}+c_{\Psi}^{2}+e_{\Psi}^{2}
\end{array}
$$

Twin 2

Self-employed ( $\Psi)$

$$
\begin{aligned}
0.5 r_{A} a_{\Phi} a_{\Psi}+r_{C} c_{\Phi} c & r_{A} a_{\Phi} a_{\Psi}+r_{C} c_{\Phi} c_{\Psi} \\
& +r_{E} e_{\Phi} e_{\Psi}
\end{aligned}
$$

$$
0.5 a_{\Psi}^{2}+c_{\Psi}^{2} \quad a_{\Psi}^{2}+c_{\Psi}^{2}+e_{\Psi}^{2}
$$

Table 1: Genetic modeling analysis for current self-employment

\begin{tabular}{|l|l|l|l|l|l|l|l|l|}
\hline Model & $\mathbf{A ~ ( 9 5 \% ~ C I ) ~}$ & $\mathbf{C ~ ( 9 5 \% ~ C I ) ~}$ & $\mathbf{E ~ ( 9 5 \% ~ C I ) ~}$ & $\chi^{2}$ & $\mathbf{d f}$ & $\mathbf{p}$ Value & AIC & RMSEA \\
\hline ACE & $0.38(0$ to & $0.09(0$ to & $0.53(0.35$ to & 2.30 & 3 & 0.51 & -3.70 & 0.001 \\
& $0.65)$ & $0.53)$ & $0.75)$ & & & & & \\
\hline CE & - & $0.40(0.22$ to & $0.60(0.45$ to & 3.48 & 4 & 0.48 & -4.52 & 0.001 \\
& $0.55)$ & $0.78)$ & & & & & \\
\hline$A E$ & $0.48(0.28$ to & - & $\begin{array}{l}0.52(0.35 \text { to } \\
0.72)\end{array}$ & 2.39 & 4 & 0.66 & -5.61 & 0.001 \\
& $0.65)$ & & & & & & \\
\hline
\end{tabular}

Table 2: Genetic modeling analysis for past self-employment

\begin{tabular}{|l|l|l|l|l|l|l|l|l|}
\hline Model & $\mathbf{A ~ ( 9 5 \% ~ C I ) ~}$ & $\mathbf{C ~ ( 9 5 \% ~ C I )}$ & $\mathbf{E ~ ( 9 5 \% ~ C I ) ~}$ & $\chi^{\mathbf{2}}$ & $\mathbf{d f}$ & $\mathbf{p}$ Value & AIC & RMSEA \\
\hline ACE & $0.64(0.10$ to & $0(0$ to 0.47$)$ & $0.36(0.21$ to & 5.82 & 3 & 0.12 & -0.19 & 0.025 \\
& $0.79)$ & & $0.54)$ & & & & & \\
\hline CE & - & $0.53(0.36$ to & $0.47(0.33$ to & 10.9 & 4 & 0.02 & 2.94 & 0.069 \\
& & $0.67)$ & $0.64)$ & 4 & & & & \\
\hline$A E$ & $0.64(0.46$ to & - & $\begin{array}{l}0.36(0.21 \text { to } \\
0.54)\end{array}$ & 5.82 & 4 & 0.21 & -2.19 & 0.022 \\
& $0.79)$ & & $0.54)$ & & & \\
\hline
\end{tabular}


Table 3: Genetic effects on self employment for males only

\begin{tabular}{|l|l|l|l|l|l|l|l|l|}
\hline Variable & Model & $\begin{array}{l}\mathbf{A ~ ( 9 5 \%} \\
\text { CI) }\end{array}$ & $\begin{array}{l}\text { E (95\% } \\
\text { CI) }\end{array}$ & $\chi^{2}$ & df & p Value & AIC & RMSEA \\
\hline $\begin{array}{l}\text { Current self- } \\
\text { employment }\end{array}$ & $A E$ & $\begin{array}{l}0.59(0.34 \\
\text { to } 0.78)\end{array}$ & $\begin{array}{l}0.41 \quad(0.22 \\
\text { to } 0.66)\end{array}$ & 2.98 & 4 & 0.56 & -5.02 & 0.001 \\
\hline $\begin{array}{l}\text { Past self- } \\
\text { employment }\end{array}$ & $A E$ & $\begin{array}{l}0.70(0.47 \\
\text { to } 0.86)\end{array}$ & $\begin{array}{l}0.30 \quad(0.14 \\
\text { to } 0.53)\end{array}$ & 6.63 & 4 & 0.16 & -1.37 & 0.046 \\
\hline
\end{tabular}

Table 4: Genetic modeling analysis for entrepreneurial intentions

\begin{tabular}{|c|c|c|c|c|c|c|c|c|}
\hline Model & A (95\% CI) & C (95\% CI) & E $(95 \%$ CI $)$ & $\chi^{2}$ & df & p Value & AIC & RMSEA \\
\hline $\mathrm{ACE}$ & $\begin{array}{lll}0.29 & (0 \quad \text { to } \\
0.57) & & \end{array}$ & $\begin{array}{lll}0.11 & (0 \quad \text { to } \\
0.47) & \end{array}$ & $\begin{array}{l}0.59(0.43 \text { to } \\
0.78)\end{array}$ & 8.68 & 3 & 0.03 & 2.68 & 0.068 \\
\hline $\mathrm{CE}$ & - & $\begin{array}{l}0.35(0.20 \text { to } \\
0.49)\end{array}$ & $\begin{array}{l}0.65(0.51 \text { to } \\
0.80)\end{array}$ & 9.63 & 4 & 0.05 & 1.64 & 0.059 \\
\hline$A E$ & $\begin{array}{l}0.42(0.25 \text { to } \\
0.57)\end{array}$ & - & $\begin{array}{l}0.58(0.43 \text { to } \\
0.75)\end{array}$ & 8.86 & 4 & 0.07 & 0.86 & 0.054 \\
\hline
\end{tabular}

Table 5: Cross trait cross twin correlations between the propensity of people to have engaged in self-employment and entrepreneurial intentions

\begin{tabular}{|c|c|c|c|c|}
\hline & $\begin{array}{l}\text { Twin 1 } \\
\text { Past self- } \\
\text { employment } \\
\end{array}$ & $\begin{array}{l}\text { Twin 2 } \\
\text { Past self- } \\
\text { employment }\end{array}$ & $\begin{array}{l}\text { Twin 1 } \\
\text { Entrepreneurial } \\
\text { intentions }\end{array}$ & $\begin{array}{l}\text { Twin } 2 \\
\text { Entrepreneurial } \\
\text { intentions }\end{array}$ \\
\hline MZ twins & & 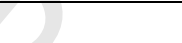 & & \\
\hline $\begin{array}{l}\text { Twin 1 } \\
\text { Past self- } \\
\text { employment }\end{array}$ & 1 & & & \\
\hline $\begin{array}{l}\text { Twin } 2 \\
\text { Past self- } \\
\text { employment }\end{array}$ & .41 & 1 & & \\
\hline $\begin{array}{l}\text { Twin 1 } \\
\text { Entrepreneurial } \\
\text { intentions }\end{array}$ & .38 & .15 & 1 & \\
\hline $\begin{array}{l}\text { Twin } 2 \\
\text { Entrepreneurial } \\
\text { intentions }\end{array}$ & .24 & .31 & .26 & 1 \\
\hline \multicolumn{5}{|l|}{ DZ twins } \\
\hline $\begin{array}{l}\text { Twin 1 } \\
\text { Past self- } \\
\text { employment }\end{array}$ & 1 & & & \\
\hline $\begin{array}{l}\text { Twin } 2 \\
\text { Past self- } \\
\text { employment }\end{array}$ & .10 & 1 & & \\
\hline $\begin{array}{l}\text { Twin } 1 \\
\text { Entrepreneurial } \\
\text { intentions }\end{array}$ & .37 & .11 & 1 & \\
\hline $\begin{array}{l}\text { Twin } 2 \\
\text { Entrepreneurial } \\
\text { intentions }\end{array}$ & .10 & .24 & .13 & 1 \\
\hline
\end{tabular}


Table 6: Genetic modeling analysis for Managers

\begin{tabular}{|c|c|c|c|c|c|c|c|c|}
\hline Model & $A(95 \%$ CI $)$ & $\mathrm{C}(95 \% \mathrm{CI})$ & E (95\% CI) & $\chi^{2}$ & df & p Value & AIC & RMSEA \\
\hline $\mathrm{ACE}$ & $\begin{array}{lll}0.27 & (0 \quad \text { to } \\
0.48) & & \end{array}$ & $\begin{array}{lll}0.02 & (0 \quad \text { to } \\
0.38) & & \end{array}$ & $\begin{array}{l}0.71(0.52 \text { to } \\
0.92)\end{array}$ & 1.79 & 3 & 0.62 & -4.21 & 0.001 \\
\hline $\mathrm{CE}$ & - & $\begin{array}{l}0.24(0.07 \text { to } \\
0.40)\end{array}$ & $\begin{array}{l}0.76(0.60 \text { to } \\
0.93)\end{array}$ & 2.41 & 4 & 0.66 & -5.59 & 0.001 \\
\hline$\overline{A E}$ & $\begin{array}{l}0.30(0.09 \text { to } \\
0.48)\end{array}$ & - & $\begin{array}{l}0.70(0.52 \text { to } \\
0.91)\end{array}$ & 1.80 & 4 & 0.77 & -6.20 & 0.001 \\
\hline
\end{tabular}

Table 7: Genetic modeling analysis for sales related occupation

\begin{tabular}{|l|l|l|l|l|l|l|l|l|l|}
\hline Model & $\mathbf{A ~ ( 9 5 \% ~ C I ) ~}$ & $\mathbf{C ~ ( 9 5 \% ~ C I ) ~}$ & $\mathbf{E ~ ( 9 5 \% ~ C I ) ~}$ & $\chi^{2}$ & $\mathbf{d f}$ & $\mathbf{p}$ Value & AIC & RMSEA \\
\hline ACE & $0.46(0$ to & $0.00(0$ to & $0.54(0.30$ to & 0.29 & 3 & 0.96 & -5.72 & 0.001 \\
& $0.70)$ & $0.55)$ & $0.85)$ & 5 & & & & \\
\hline CE & - & $0.36(0.11$ to & $0.64(0.43$ to & 1.33 & 4 & 0.86 & -6.67 & 0.001 \\
& & $0.57)$ & $0.89)$ & & & & & \\
\hline$A E$ & $0.46(0.16$ to & - & $\begin{array}{l}0.54(0.30 \text { to } \\
0.84)\end{array}$ & 0.29 & 4 & 0.99 & -7.72 & 0.001 \\
\hline
\end{tabular}

Table 8: Genetic modeling analysis for teachers

\begin{tabular}{|c|c|c|c|c|c|c|c|c|}
\hline Model & $A(95 \%$ CI $)$ & C (95\% CI) & E $(95 \%$ CI) & $\chi^{2}$ & df & p Value & AIC & RMSEA \\
\hline $\mathrm{ACE}$ & $\begin{array}{lll}0.43 & (0 \quad \text { to } \\
0.72) & & \end{array}$ & $\begin{array}{ll}0.00 & (0 \quad \text { to } \\
0.45)\end{array}$ & $\begin{array}{l}0.57 \text { (0.28 to } \\
0.94)\end{array}$ & 4.40 & 3 & 0.22 & -1.60 & 0.036 \\
\hline $\mathrm{CE}$ & - & $\begin{array}{l}0.27 \\
0.54)\end{array} \quad$ (0 to & $\begin{array}{l}0.73 \text { (0.46 to } \\
1.00)\end{array}$ & 6.75 & 4 & 0.15 & -1.25 & 0.034 \\
\hline$A E$ & $\begin{array}{l}0.43(0.06 \text { to } \\
0.72)\end{array}$ & & $\begin{array}{l}0.57(0.28 \text { to } \\
0.94)\end{array}$ & 4.40 & 4 & 0.35 & -3.60 & 0.028 \\
\hline
\end{tabular}

